\title{
Psychological capital: Internal and external validity of the Psychological Capital Questionnaire (PCQ-24) on a South African sample
}

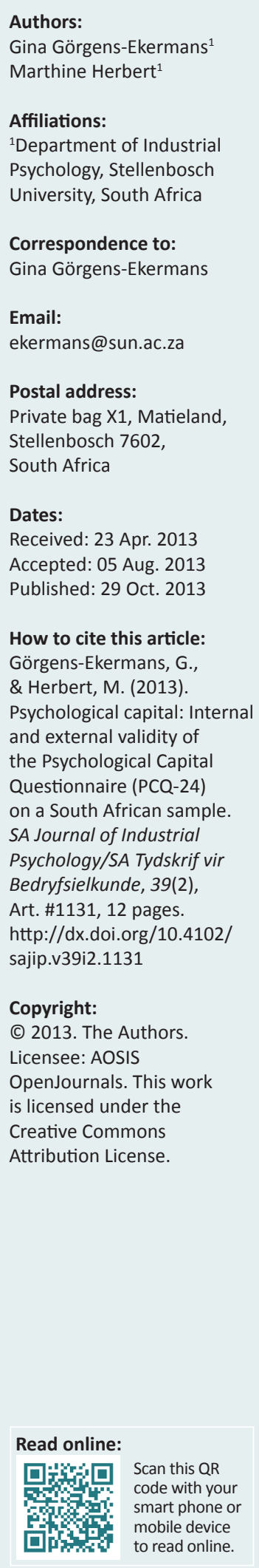

Authors:

Gina Görgens-Ekermans

\section{Affiliations:}

1Department of Industrial Psychology, Stellenbosch University, South Africa

\section{Correspondence to:}

Email:

\section{Postal address:}

Private bag X1, Matieland, Stellenbosch 7602,

South Africa

Accepted: 05 Aug 2013

Published: 29 Oct. 2013

How to cite this article:

Psychological capital: Internal and external validity of on a South African sample. SA Journal of Industrial Psychology/SA Tydskrif vir Bedryfsielkunde, 39(2) Art. \#1131, 12 pages. http://dx.doi.org/10.4102/ Copyright: C 2013. The Authors. Licensee: AOSIS OpenJournals. This wor is licensed under the Creative Commons Attribution License.
Orientation: Psychological capital (PsyCap) is a relatively novel construct measured with the Psychological Capital Questionnaire 24 (PCQ-24). Only one published South African study on the instrument exists, providing inconsistent psychometric results, when compared with other United States of America (USA) and non-USA studies.

Research purpose: The objectives of this study were to investigate the internal validity (construct and discriminant validity), reliability and external validity (relationship with theoretically relevant variables, namely stress, burnout and work engagement) of the PCQ-24.

Motivation for the study: Multiple studies have underscored the value of PsyCap within the workplace. In order to harness the full potential of the construct in the South African environment, sound measurement thereof, evidenced by a psychometrically sound instrument, is needed.

Research design, approach and method: A cross-sectional survey design was used. The sample consisted of employees at managerial and non-managerial levels, from a medium-sized construction company in the Western Cape, South Africa. In addition to PsyCap, perceived stress, work-related burnout and work engagement were measured.

Main findings: The results provided preliminary evidence of construct and discriminant validity, reliability and significant relations with external theoretically relevant variables.

Practical/managerial implications: Researchers may confidently use the PCQ-24 to measure the construct of PsyCap and investigate relations with workplace outcomes in the South African environment, informing human relations practices.

Contribution/value-add: Preliminary evidence of the psychometric properties of the PCQ-24, which measures the construct of PsyCap (consisting of hope, self-efficacy, resilience and optimism) on a South African sample, was provided in this study.

\section{Introduction}

\section{Key focus and problem statement}

Occupational stress and burnout are serious problems in modern organisations. The cost of high stress and burnout levels to employers include higher staff turnover, lower morale, excessive sick leave and reduced productivity and efficiency (e.g. Cordes \& Dougherty, 1993; Lee \& Ashforth, 1996; Schaufeli \& Enzmann, 1998; Wright \& Bonett, 1997). Studies from the emerging field of positive organisational behaviour (POB) (Luthans, 2002) have shown that the construct of psychological capital (PsyCap) (i.e. a higher order constellation of positive psychological components that consists of hope, optimism, self-efficacy and resilience), may contribute to decreased stress (e.g. Avey, Luthans \& Jensen, 2009) and increased work engagement (Avey, Wernsing \& Luthans, 2008). Within the framework of Hobfoll's (2002) psychological resources theory, Luthans, Youssef and Avolio (2007, p. 10) define PsyCap as 'an individual's positive psychological state of development, characterised by: (1) having confidence (self-efficacy) to take on and put in the necessary effort to succeed at challenging tasks; (2) making a positive attribution (optimism) about succeeding now and in the future; (3) persevering towards goals, and when necessary, redirecting paths to goals (hope) in order to succeed; and (4) when beset by problems and adversity, sustaining and bouncing back and even beyond (resiliency) to attain success'. In essence, PsyCap represents an individual's, 'positive appraisal of circumstances and probability for success based on motivated effort and perseverance' (Luthans, Avolio, Avey \& Norman, 2007, p. 550). PsyCap has been shown to impact a range of workplace outcomes like job performance (Luthans, Avolio, Avey \& Norman, 2007; Luthans, Avolio, Walumbwa \& Li, 2005), stress (e.g. Avey et al., 2009) and well-being (Culberson, Fullagar \& Mills, 2010). 
Given the promise that the construct of PsyCap may hold as a personal resource that may affect various health-related and other workplace outcomes, the measurement thereof (i.e. Psychological Capital Questionnaire - Self Rater Version, PCQ-24, Luthans, Avolio, Avey \& Norman, 2007) should be validated for use within the South African context. It is not uncommon to use foreign-developed psychological tests (e.g. PCQ-24 developed in the USA) in South Africa (Oakland, 2004). However, test transportability should be substantiated by investigating the psychometric properties of the instrument when used on a South African sample. This study attempted to provide internal and external validation (in terms of outcomes related to PsyCap) evidence in favour of using the PCQ-24 as a measure of the PsyCap construct within South Africa.

\section{Background to the study}

Psychological capital is a relatively novel construct. The PCQ-24 was developed abroad (i.e. USA). The instrument can be considered a monocentered instrument (Van de Vijver \& Leung, 2001), that is an instrument stemming from a single Western cultural background. Hence, the portability of the PCQ-24 to a culturally diverse and predominantly non-Western environment should be investigated, before inferences derived from the measure can be used with confidence within the South African environment. Currently only one published South African study (Du Plessis \& Barkhuizen, 2011) reporting on the factor structure of the PCQ-24 exist. According to the authors the results of the EFA revealed a three-factor structure underlying the PCQ-24 (based on a predominantly White, male sample), suggesting the merging of the self-efficacy (confidence) and hope sub-dimensions. However, the results were not clearly interpretable, given the fact that multiple items cross-loaded and most of the original items did in fact not load on the intended dimensions they were designed to reflect ( Du Plessis \& Barkhuizen, 2011). No CFA was conducted on the instrument in that study. These results, as well as the current dearth of research on the portability of the PCQ-24 to the South African environment, informed this study.

According to Luthans, Youssef \& Avolio (2007), PsyCap was founded on theoretical frameworks that have been widely recognised (e.g. social cognitive theory, Bandura, 1986; hope theory, Snyder, 2000). The four scales that were included in the development phase of the instrument were selected based on sound reliability and validity evidence, clear relevance to the workplace and being measures of state-like constructs (Luthans, Avolio, Avey \& Norman, 2007). Based on these criteria, the following four scales were included: hope (Snyder et al., 1996), resilience (Wagnild \& Young, 1993), optimism (Scheier \& Carver, 1985) and self-efficacy (Parker, 1998) (Luthans, Avolio, Avey \& Norman, 2007). Items from these scales were pooled and formed the basis for the development of the PCQ-24. Two criteria informed the development process. Firstly, all four constructs were assigned an equal weight, to enable the selection of the six best items from every measure. Secondly, selected items were evaluated for face and content validity, being state-like and relevant to the workplace. Internal consistency for the PCQ-24 on the four samples reported in Luthans, Avolio, Avey and Norman (2007) ranged from 0.72 to 0.80 for hope, 0.66 to 0.72 for resilience, 0.75 to 0.85 for self-efficacy and 0.69 to 0.79 for optimism. The results of a series of higher-order confirmatory factor analyses (CFAs) (also cross-validated on another sample) provided strong evidence for the higherorder factor structure for the overall PsyCap measure (i.e. the root mean square error of approximation [RMSEA] $=0.046$; Comparative fit index $[\mathrm{CFI}]=0.93$, standardised root mean residual $[S R M R]=0.051$ ) (Luthans, Avolio, Avey \& Norman, 2007). A further series of competing CFAs were reported that examined statistical differences in model fit between the higher-order model and multiple three-factor models (different combinations of the facets) as well as a one-factor model, providing further rigorous evidence confirming the higher-order PsyCap factor. These results (higher-order model, as well as competing models analyses) have been replicated in subsequent studies (e.g. Luthans, Avey, Avolio \& Peterson, 2010).

Multiple studies have confirmed the value of PsyCap within the workplace. For example, PsyCap has been shown to be a powerful predictor of performance (Luthans et al., 2010) and satisfaction (Luthans, Avolio, Avey \& Norman, 2007; Luthans, Norman, Avolio \& Avey, 2008), in-role performance (Gooty, Gavin, Johnson, Frazier \& Snow, 2009) and creative performance (Sweetman, Luthans, Avey, \& Luthans, 2011), as well as organisational commitment (Luthans et al., 2008). The notable research component on the effect of PsyCap on employee performance has recently been expanded with a longitudinal study (Peterson, Luthans, Avolio, Walumbwa \& Zhang, 2011) confirming the impact of PsyCap on both subjective and objective performance over time. In addition, a recent meta-analysis (Avey, Reichard, Luthans \& Mhatre, 2011) based on 51 samples ( $n=12567$, although most studies included were yet to be published) provided convincing evidence for the strong significant relationships that PsyCap exhibits with desirable (i.e. satisfaction, commitment and psychological well-being) and undesirable (i.e. cynicism, turnover intentions, stress and anxiety) employee attitudes, as well as with both positive and negative behaviours (i.e. organisational citizenship behaviours, deviance) and, most notably, with employee performance.

Considerable research has also highlighted the health enhancing capacity of PsyCap. PsyCap has consistently been shown to correlate negatively with stress (Avey et al., 2009; Avey, Reichard, Luthans \& Mhatre, 2011; Liu, Chang, Fu, Wang \& Wang, 2012; Roberts, Scherer \& Bowyer, 2011) and burnout (Cheung, Tang \& Tang, 2011; Laschinger \& Grau, 2012; Wang, Chang, Fu \& Wang, 2012). Moreover, PsyCap has been shown to be a moderator in the emotional labourburnout relationship (Cheung et al., 2011). Numerous studies underscore the importance of PsyCap as a predictor of employee well-being (Avey, Luthans, Smith \& Palmer, 2010; Culbertson et al., 2010; Tripathi, 2011), with a recent 
longitudinal study showing that positive emotions and stress mediate the relationship between PsyCap and well-being (Avey, Wernsing \& Mhatre, 2011).

In addition to studies conducted in the USA, to date, published PsyCap research has been conducted on samples from China (Cheung et al., 2011; Liu et al., 2012; Wang et al., 2012), India (Tripathi, 2011), Canada (Laschinger \& Grau, 2012), the United Kingdom (Nigah, Davis \& Hurrell, 2012), Portugal (Rego, Sousa, Marques \& Cunda, 2012) and South Africa (Du Plessis \& Barkhuizen, 2011). It is clear that research interest, as evidenced by a recent review (Dawkins, Martin, Scott \& Sanderson, 2013), as well as the practical utility of PsyCap in the workplace continue to grow. In most of these studies conducted in other countries, the PCQ-24 demonstrated fairly consistent psychometric properties with those reported by Luthans, Avolio, Avey \& Norman (2007) (for a full review see Dawkins et al., 2013). However, the results of the only published South African study (Du Plessis \& Barkhuizen, 2011) to date are not consistent with the general psychometric trends reported for the instrument in studies from other countries. Well-established evidence of validity and reliability should be a prerequisite for utilising an imported measure, such as the PCQ-24, in the local environment. Given the promise the construct holds to predict various workplace outcomes and inform workplace intervention strategies, a South African validation study was needed.

\section{Trends from the research literature}

According to Schlebusch (1998), stress is defined as the interaction of numerous variables in the context of a person and environment relationship, which is appraised as taxing, exceeding coping resources and endangering well-being. Burnout as an extreme case of chronic, prolonged stress (Maslach \& Goldberg, 1998; Schaufeli \& Enzmann, 1998) is likely to emerge when work is unchallenging, unrewarding and lacking in positive feedback and recognition (Maslach, 1982). The core of work burnout is fatigue and exhaustion (Kristensen, Borritz, Villadsen \& Christensen, 2005). It is well known that burnout is a serious problem in most professions (e.g. Cordes \& Dougherty, 1993) with organisational level negative consequences ranging from increased staff turnover and absenteeism, low employee morale, increased intention to quit, to lowering quality and quantity of job performance (Cordes \& Dougherty, 1993; Cropanzano, Rupp, \& Byrne, 2003; Du Plooy \& Roodt, 2010; Lee \& Ashforth, 1996; Schaufeli \& Enzmann, 1998; Wright \& Bonett, 1997).

Traditionally, organisational intervention strategies have been directed at the amelioration of stress and burnout. This approach fosters a narrow focus on distinct adverse work experiences and negative employee emotional responses (e.g. Cotton \& Hart, 2003). Moreover, positive emotional responses and work experiences, which are usually not considered in stressor and strain approaches, have been associated with individual well-being outcomes (e.g. Diener, 2000). Hobfoll's (1989) Conservation of Resource (COR) theory states that the acquiring and maintaining of resources will result in increased well-being. According to the theory, these resources include physical objects, personal characteristics (such as PsyCap), energies and conditions (Hobfoll, 1989). In addition, Avey, Reichard, Luthans and Mhatre (2011) hold that PsyCap has a synergistic effect, due to the fact that it incorporates the coping mechanisms the four individual sub-dimensions have in common. Hence, PsyCap has been shown to be related to hedonic and eudaimonic well-being (Culbertson et al., 2010). Moreover, PsyCap has been shown to be a predictor of employee psychological well-being over time (Avey, Luthans, Smith \& Palmer, 2010). In this study, it was therefore argued that PsyCap may embody positive psychological capacities which serve as a personal characteristic resource that may have the ability to increase coping resources; this should lessen experienced stress, as well as buffer the development of work-related burnout from stress, due to the health-enhancing capabilities of, and coping mechanisms embodied by, PsyCap.

Furthermore, it is well documented that some individuals, regardless of high job demands and long working hours, do not develop burnout (e.g. Schaufeli \& Bakker, 2001). Such individuals find pleasure in working hard and dealing with job demands. From a positive psychology perspective (Seligman \& Csikszentmihalyi, 2000), such individuals could be described as engaged in their work. Two viewpoints on the burnout-work engagement relationship can be identified in the literature. The constructs are either viewed as opposite poles on a continuum (measured using the Maslach Burnout Inventory, Maslach, Jackson \& Leiter, 1986) or as fundamentally different constructs implying different operational definitions and measurements (Schaufeli \& Bakker, 2004). The latter approach was applied in this study. The focus on engagement as the positive antithesis of burnout promises to yield new perspectives on the interventions to promote healthy perceptions, beliefs and physical wellbeing (Salovey, Rothman, Detweiler \& Steward, 2000), and to alleviate burnout (Maslach, Schaufeli \& Leiter, 2001). For example, the inverse relationship between work engagement and occupational stress and burnout is well documented (e.g. Rothmann, Steyn \& Mostert, 2004). Employee engagement is positively related to business unit performance (i.e. customer satisfaction and loyalty, profitability, productivity, turnover and safety) (Harter, Schmidt, \& Hayes, 2002), customer satisfaction (Salanova, Agut \& Peiro, 2005) and financial returns (Xanthopoulou, Bakker, Demerouti \& Schaufeli, 2009). Knowledge of the predictive value of hope, optimism, resilience and self-efficacy as PsyCap components on work engagement could be beneficial in informing intervention strategies directed at increasing work engagement, as PsyCap has been shown to be state-like (e.g. Avey, Luthans \& Youssef, 2010) and open to change and development (e.g. Luthans, Avey \& Patera, 2008; Luthans et al., 2010).

\section{Potential value added by the study and research objectives}

Rectifying deficient past practices used in South Africa, of mainly importing psychological measures from abroad 
(Foxcroft, 1997) without giving due attention to the portability of psychometric properties of such instruments, has recently received increased research attention. The psychometric properties of imported measures should be investigated and be shown to meet standard requirements of validity and reliability (Foxcroft, Roodt \& Abrahams, 2001) before such instruments can be applied with confidence in the local environment. This study seeks to adhere to the call to provide preliminary psychometric evidence of an imported measure, the PCQ-24 (Luthans, Avolio, Avey \& Norman, 2007) by providing preliminary information on its internal validity (construct and discriminant validity and reliability). In addition, the study further seeks to investigate the external validity of the PCQ-24 within the South African environment by examining its relationship with other theoretically relevant variables (i.e. perceived stress, work-related burnout and work engagement).

Therefore, the objectives of this study were to investigate, in relation to the instrument, its:

- construct validity

- discriminant validity (of the different PsyCap subdimensions)

- reliability

- relationships with theoretically relevant external variables (i.e. perceived stress, work-related burnout and work engagement).

\section{Hypotheses for this study}

In the next section, the following hypotheses will be tested to reach the objectives of this study:

- Objective 1 (reliability)

- Hypothesis 1: All the sub-dimensions of the PCQ-24 (i.e. hope, optimism, self-efficacy and resilience) are reliable (i.e. Cronbach's alpha coefficients $\geq 0.70$ ).

- Objective 2 (construct validity)

- Hypothesis 2a: PsyCap is a four-dimensional construct, consisting of hope, optimism, self-efficacy and resilience.

- Hypothesis 2b: A higher-order factor, i.e. PsyCap, underlies the four PCQ-24 sub-dimensions (hope, optimism, self-efficacy and resilience).

- Objective 3 (discriminant validity)

- Hypothesis 3: The four PsyCap dimensions are, although highly related, empirically distinct constructs.

- Objective 4 (external validity)

- Hypothesis 4: PsyCap (total score) and the individual sub-dimensions are negatively related to perceived stress.

- Hypothesis 5: PsyCap (total score) and the individual sub-dimensions are negatively related to work-related burnout.

- Hypothesis 6: The PsyCap sub-dimensions are predictors of work engagement (measured in terms of vigour, dedication and absorption).

- Hypothesis 7: PsyCap (total score) is a moderator in the stress-work-related burnout relationship.

\section{Research design \\ Research approach}

A non-experimental research design (Kerlinger \& Lee, 2000) was used in this study. The use of a cross-sectional survey design (or ex post facto correlational design) is deemed appropriate in instances where interrelationships amongst variables within a population, without any manipulation or control of variables, will be assessed (Kerlinger \& Lee, 2000). Non-probability sampling (i.e. availability or convenience sampling) was used.

\section{Research method}

\section{Research participants}

The sample consisted of permanent employees within a medium-sized construction company that operates within the property development and construction industry in South Africa. Invitations for participation were extended to all employees at non-managerial, managerial and senior managerial levels, from various departments within the company.

Overall, 209 respondents (69.4\% male, 29.2\% female; age: mean $=35.34, \mathrm{SD}=10.26)$ participated in the research. The ethnic composition was: $45.9 \%$ White, $38.3 \%$ mixed-race, $12.4 \%$ Black and $2.9 \%$ Asian participants; ethnic data was missing for $0.5 \%$ of the sample. The sample was reasonably representative of all hierarchical levels in the company. For example, $30.1 \%$ of the respondents were in non-management positions, $24.4 \%$ held junior management positions, $25.4 \%$ were at middle management level, whilst $15.3 \%$ operated at senior management levels and above. Most of the respondents worked in the construction department $(34.9 \%)$. This was followed by finance (15.3\%) and building (10\%) departments. A sizable proportion of the respondents had completed a national diploma or national higher diploma (32.5\%), $12.4 \%$ had obtained a bachelor's degree, whilst $6.2 \%$ had obtained a post-graduate qualification. Eighteen participants (8.6\%) held only a secondary school qualification; $24.9 \%$ reported having a grade 12 qualification and data was missing for $1.4 \%$. A total of $56.5 \%$ of participants indicated Afrikaans to be their first language, 32.1\% English and 6.7\% IsiXhosa.

\section{Measuring instruments}

Demographic information: A biographical questionnaire was administered to record socio-demographic and biographical data of the participants. Information was collected on age, gender, ethnic group, first language, level of education, as well as hierarchical and departmental distribution within the organisation.

Burnout: Work burnout was measured with the Copenhagen Burnout Inventory ([CBI]; Kristensen et al., 2005). The core of burnout, according to the CBI, is fatigue and exhaustion. The inventory consists of three subscales: personal burnout, work-related burnout and client-related burnout. Given that the emphasis in this study was on burnout due to work experiences in general (and not, for example, burnout as 
experienced in working with clients), only the work-related burnout sub-scale was utilised in this study. Work-related burnout (Kristensen et al., 2005) refers to the degree of physical and psychological fatigue and exhaustion that is perceived by the person as related to their work (sample item: 'Are you exhausted in the morning at the thought of another day at work?'). Respondents are required to indicate their feelings about six items on a five-point Likert scale. Depending on the item the response scale would range from 1 ('never') to 5 ('always') or from 1 ('to a very high degree') to 5 ('to a very low degree'). Higher scores are indicative of less burnout. The inventory contains no negatively worded items. In the CBI validation study (Kristensen et al., 2005) good internal consistency for the work burnout subscale $(\alpha=.87)$ on a sample of Danish employees $(n=1914)$ working in the human services sector are reported. In a South African study (Meyer, 2008) an alpha of 0.77 for this scale was reported.

Stress: The Perceived Stress Scale ([PSS]; Cohen, Kamarck \& Mermelstein, 1983) was used to measure occupational stress. This measure assesses the degree to which situations in one's life are appraised to be stressful (sample item: 'In the last month, how often have you felt nervous and stressed?'). The PSS has 14 items which are designed to tap into the degree to which respondents find their lives (1) unpredictable, (2) uncontrollable and (3) overloaded (Cohen et al., 1983) as these three dimensions have been repeatedly found to be central components of the experience of stress. Participants respond by making use of a five-point Likert scale ranging from 0 ('never') to 4 ('very often'). Higher scores indicate more perceived stress. The PSS has been shown to have adequate internal reliability, as the reported coefficient alphas over three samples reported in the validation study (Cohen et al., 1983 ) were $0.84,0.85$ and 0.86 , respectively.

Psychological capital: PsyCap was measured with the PCQ24. The PCQ-24 comprises four subscales with equal weight: (1) hope, (2) optimism, (3) self-efficacy and (4) resilience. Each of these subscales consists of six items with response options on a six-point Likert scale ranging from 1 ('strongly disagree') to 6 ('strongly agree'). Each of the four subscales was drawn from established scales previously published, tested and used in recent workplace studies. More specifically, the hope items were adapted from Snyder et al.'s (1996) State Hope Scale, the optimism items from Scheier and Carver's (1985) Measure of Optimism, the self-efficacy items from Parker's (1998) measure of self-efficacy in the workplace and resilience from Wagnild and Young's (1993) Resilience Scale. Good internal consistency for the respective subscales (hope: 0.72, $0.75,0.80,0.76$; optimism: $0.74,0.69,0.76,0.79$; self-efficacy: $0.75,0.84,0.85,0.75$; and resilience: $0.71,0.71,0.66,0.72)$ on the four samples utilised in the Luthans, Avolio, Avey, \& Norman (2007) study were reported.

Engagement: The shortened Utrecht Work Engagement Scale (UWES-9) (Schaufeli \& Bakker, 2003) was used to measure employee engagement. The UWES makes use of a sevenpoint frequency scale ranging from 0 ('never') to 6 ('always') and consists of three scales (each with three items): vigour (characterised by high levels of energy and mental resilience, investing effort in, and persisting in the face of difficulties when working, e.g. 'At my work, I feel bursting with energy'), dedication (characterised by experiencing a sense of significance, enthusiasm, inspiration, pride and challenge in work, e.g. 'My job inspires me') and absorption (characterised by being happily engrossed in work or finding it hard to detach oneself from work, e.g. 'I get carried away when I'm working'). Multiple international (e.g. Schaufeli \& Bakker, 2003) and national studies (e.g. De Braine \& Roodt, 2011) have proven the internal consistency of the three subscales of the different versions (i.e. nine-item, 17-item) of the test.

Construct validity of the measuring instruments was tested by fitting CFA measurement models with LISREL 8.8 (Du Toit \& $\mathrm{Du}$ Toit, 2001). The results supported a one-factor model for the work-related burnout subscale of the CBI: Satorra Bentler Chi-square $\left(\mathrm{S}-\mathrm{B} \chi_{(14)}^{2}\right)=42.69 ; p<0.05$; non-normed fit index $[\mathrm{NNFI}]=0.94 ; \mathrm{CFI}=0.96 ; \mathrm{SRMR}=0.05$ and $\mathrm{RMSEA}=0.10$ ). Completely standardised factor loadings ranged from 0.48 to 0.74 . The results supported the three-factor structure of the UWES-9: S-B $\chi_{(24)}^{2}=59.36 ; p<0.05 ; \mathrm{NNFI}=0.97 ; \mathrm{CFI}=0.98$; SRMR $=0.06$ and RMSEA $=0.08$. Completely standardised factor loadings ranged from 0.51 to 0.92 . The initial results for the one-factor stress scale (PSS) raised some concern: $\mathrm{S}-\mathrm{B} \chi_{(77)}^{2}=323.86 ; p<0.05 ; \mathrm{NNFI}=0.83 ; \mathrm{CFI}=0.86$; $\mathrm{SRMR}=0.12$ and RMSEA $=0.13$. Results of all the Goodness-of-Fit (GOF) indices pointed towards a very poor-fitting model. Hence, exploratory factor analysis (EFA) was conducted (principle axis factoring with direct oblimin rotation) on this scale. The extraction of factors was based on the scree test and 'eigenvalue bigger than 1 ' rule. Based on the results of the item analysis, one item (item 12, 'In the last month, how often have you found yourself thinking about things that you have to accomplish?') was identified as a poor item (low corrected item-total correlation of $-0.16, \Delta \alpha=0.02$ if deleted). This item was not included in the EFA. The results of the EFA revealed that two factors could be extracted, accounting for 52.65\% of the variance. Upon evaluation of the item content it was evident that the two factors reflected method factors related to the scale item wording (positively and negatively phrased items). Hence, a CFA was conducted modelling the two method factors together with the stress latent trait variable. The results $\left(\mathrm{S}-\mathrm{B} \chi_{(51)}^{2}=92.38, p<0.05 ; \mathrm{NNFI}=0.96\right.$; $\mathrm{CFI}=0.98$; $\mathrm{SRMR}=0.05$ and $\mathrm{RMSEA}=0.06$ ) provided support for the notion that method factors distorted the validity results of the initial CFA and that confidence can be placed in the one-factor model. Due to the nature of the emphasis on the PCQ-24 psychometric properties in this article, an in-depth discussion of the analysis conducted on the instrument will be reported in the results section.

\section{Research procedure}

Ethical clearance and institutional permission from the participating company was obtained prior to conducting the research. The composite questionnaire was emailed to prospective participants. Informed consent was obtained. However, participants were advised that by returning 
the completed questionnaire by email, they would forfeit anonymity. Therefore, collection boxes were also placed throughout the building into which completed questionnaires could be deposited. Construction site visits were also used to deliver and collect anonymous questionnaire packs for those employees that did not have access to email. Respondents were given two to three weeks to complete the composite questionnaire. A response rate of $66.35 \%$ was obtained.

\section{Statistical analysis}

The SPSS 18.0 for Windows ${ }^{\circledR}$ (SPSS, 2010), LISREL 8.8 (Du Toit \& Du Toit, 2001) and PRELIS 2.8 (Jöreskog \& Sörbom, 2002) were used for analysing the data. Item analysis, confirmatory factor analysis and exploratory factor analysis were performed to investigate the psychometric integrity of the measurement instruments. Pearson's product-moment correlations were calculated and multiple regressions were conducted.

The CFA was conducted to examine the construct validity of the PCQ-24. Two competing models were fitted to the data: the four-factor model (distinguishing the four sub-dimensions) and a one-factor model (where all the items were specified to load on the higher-order PsyCap latent variable). Differences in statistical fit between these nested models were calculated with an adjustment formula proposed by Satorra and Bentler (1999). Given the design intentions of the developers of the PCQ-24, the four-factor model should fit the data significantly better than the one-factor model (where all 24 items load on one factor). To further evaluate the CFA model fit a combination of absolute and incremental GOF indices are reported: the Satorra-Bentler chi-square (Satorra \& Bentler, 1988), the comparative fit index (CFI), the non-normed fit index (NNFI), the root mean square error of approximation (RMSEA), as well as the standardised root mean square residual (SRMR). The test of close fit was also interpreted. It tests whether Ho:RMSEA is less than or equal to 0.05 and Ha:RMSEA is greater than 0.05 ; if $p$ is greater than 0.05 , close fit has been achieved. Simulation research (see Hair, Black, Babin, Anderson \& Tatham, 2006) suggests that in models with between 12 and 30 observed variables (as in this study for the PCQ-24) and sample sizes of less than 250, CFI and NNFI cut-off values of 0.95 are suggested. For the RMSEA, values under 0.05 (Diamantopoulos \& Siguaw, 2000) indicates a well-fitting model, whilst values less than 0.08 indicate reasonable fit (Vandenberg \& Lance, 2000). RMSEA values greater than 0.08 but less than 0.10 are indicative of mediocre fit and values exceeding 0.10 are generally regarded as indicative of poor fit (Diamantopoulos \& Siguaw, 2000). For the SRMR, values below 0.05 indicate that the model fits the data very well (Kelloway, 1998), whilst values less than 0.08 are considered to be indicative of acceptable model fit $(\mathrm{Hu}$ \& Bentler, 1999).

Two tests for discriminant validity were conducted. The first test involved fitting a series of CFA models to test if the subdimensions of the PCQ-24 (i.e. hope, optimism, self-efficacy and resilience) were distinct from one another. In each case the unconstrained model was the hypothesised four-factor model (M1 in Table 2). In each comparison model, one correlation between two different dimensions was fixed to equality (i.e. 1.00). For example, in the first comparison model (M2) the correlation between self-efficacy and hope was fixed to equal, suggesting a perfect correlation. The extent to which the unconstrained model fitted the data better than each of the comparison models supported the discriminant validity for the pair of constructs for which the correlation was restricted to equality (i.e. 1.00). Robust maximum likelihood estimation was employed to derive model parameter estimates producing the Satorra-Bentler chi-square statistic $\left(\mathrm{S}-\mathrm{B} \chi^{2}\right)$. Differences in statistical fit between nested models were calculated with an adjustment formula proposed by Satorra and Bentler (1999). Secondly, the magnitude of the Pearson correlations between the PsyCap sub-dimensions was inspected. According to Kline (1998), correlations of 0.60 (and less) may be interpreted as providing support for the discriminant validity.

Cronbach's alpha coefficients were used to assess the reliability of the PCQ-24. To determine the relationships of PsyCap with perceived stress and work-related burnout, Pearson's product-moment correlations were calculated. The level of statistical significance was set at below 0.05. Standard multiple regression analyses were conducted to investigate the effects of the different PsyCap sub-dimensions on the different components of work engagement.

To explore whether PsyCap acts as moderator in the occupational stress and burnout relationship, a moderated multiple regression was conducted. An interaction effect will exist when the impact of one independent variable (perceived stress, measured with the PSS) depends on the value of another independent variable (PsyCap) (Lewis-Beck, 1980). The specific type of regression used to measure the interaction effect involves forming a multiplicative term, X1X2 (in this case multiplying PSS scores with the PsyCap total score), creating a new variable named PsyCap-Interaction. In the moderated regression analysis, work-related burnout was entered as the dependent variable, and occupational stress (total score), PsyCap-Interaction (PsyCap as moderator) and PsyCap (total score) were entered as independent variables.

\section{Results}

\section{Psychometric properties of the Psychological Capital Questionnaire 24: Internal consistency}

Missing values in the dataset were imputed with PRELIS 2.8 (Jöreskog \& Sörbom, 2002) via the multiple imputation procedure, slightly attenuating the sample size to 202 cases. The means, standard deviations, reliabilities and correlations between all the study variables are reported in Table 1 . The results of the item analysis for the PCQ-24 hope $(\alpha=0.81)$ and self-efficacy ( $\alpha=0.83$ ) subscales showed no items that chould be flagged as possible poor items. Both these subscales comfortably met the $\alpha>0.70$ (Nunnally \& Bernstein, 1994) cut-off. Previous studies have consistently shown that that the optimism and resilience subscales have less internal consistency than the other two subscales in the PCQ-24 (Avey, Luthans \& Youssef, 2010; Luthans, Avolio, Avey \& 
TABLE 1: Descriptive statistics: Means, standard deviations, reliabilities, and correlations for study variables.

\begin{tabular}{|c|c|c|c|c|c|c|c|c|c|c|c|c|}
\hline Variable & $\mathbf{M}$ & SD & 1 & 2 & 3 & 4 & 5 & 6 & 7 & 8 & 9 & 10 \\
\hline \multicolumn{13}{|l|}{ Psychological capital } \\
\hline 1. Self-efficacy & 29.23 & 4.29 & 0.83 & - & - & - & - & - & - & - & - & - \\
\hline 2. Hope & 28.11 & 4.25 & $0.62^{* *}$ & 0.81 & - & - & - & - & - & - & - & - \\
\hline 3. Resilience & 28.71 & 3.62 & $0.58^{* *}$ & $0.59 * *$ & 0.69 & - & - & - & - & - & - & - \\
\hline 4. Optimism & 26.32 & 3.80 & $0.54^{* *}$ & $0.61^{* *}$ & $0.52^{* *}$ & 0.67 & - & - & - & - & - & - \\
\hline 5. PsyCap total score & 112.60 & 13.21 & $0.84^{* *}$ & $0.86^{* *}$ & $0.80 * *$ & $0.80 * *$ & 0.85 & - & - & - & - & - \\
\hline 7. Perceived stress & 23.42 & 7.19 & $-0.35^{* *}$ & $-0.39 * *$ & $-0.42 * *$ & $-0.53 * *$ & $-0.51 * *$ & $-0.59 * *$ & 0.83 & - & - & - \\
\hline \multicolumn{13}{|l|}{ Work engagement } \\
\hline 8. Vigour & 12.15 & 3.09 & $0.51^{* *}$ & $0.51^{* *}$ & $0.48^{* *}$ & $0.59 * *$ & $0.63 * *$ & $0.57 * *$ & $-0.48^{* *}$ & 0.86 & - & - \\
\hline 9. Dedication & 14.02 & 2.92 & $0.53^{* *}$ & $0.58^{* *}$ & $0.44^{* *}$ & $0.56^{* *}$ & $0.64 * *$ & $0.35 * *$ & $-0.31 * *$ & $0.73^{* *}$ & 0.85 & - \\
\hline 10. Absorption & 12.76 & 2.79 & $0.33 * *$ & $0.36 * *$ & $0.36 * *$ & $0.39 * *$ & $0.43 * *$ & $0.11 * *$ & -0.06 & $0.48^{* *}$ & $0.59 * *$ & 0.68 \\
\hline
\end{tabular}

$\mathrm{M}$, mean; SD, standard deviation; Coefficient alphas are along the diagonal.

$*, p<0.05 ;{ }^{* *}, p<0.01$

Norman, 2007). A similar trend was evident in the results of this study (optimism: $\alpha=0.67$; resilience: $\alpha=0.69$ ). Both marginally missed the 0.70 cut-off (Nunnally \& Bernstein, 1994). Results of the item analysis for the optimism subscale showed that item 20 ('If something can go wrong for me work-wise, it will') obtained a fairly lower correlation with the underlying factor, optimism, than the rest of the items within the subscale. However, only a marginal increase $(\Delta \alpha$ $=0.01$ ) in the current subscale reliability would be obtained by deleting the item. The item was therefore retained. Inspection of the item statistics for the self-efficacy subscale revealed that item 13 ('When I have a setback at work, I have trouble recovering from it, moving on') obtained a lower corrected item-total correlation than the other items in the scale. Moreover, a fairly substantial increase in the alpha would result by deleting the item $(\Delta \alpha=0.06)$. However, given the objective of investigating the properties of the PCQ-24 within the South African environment it was decided to retain these items for further analysis, but to flag them as possible problematic items that should be investigated in future studies. The current results, therefore, were interpreted to suggest partial support for Hypothesis 1 in this study.

\section{Construct validity}

The item raw values were utilised as observed variables in the CFA of the measurement model. PRELIS 2.8 (Jöreskog \& Sörbom, 2002) was used to evaluate the univariate and multivariate normality of the 24 observed variables. Results for the multivariate normality (skewness and kurtosis: $\left.\chi^{2}=1830.302 ; p<0.000\right)$ indicated that robust maximum likelihood estimation (RML) should be employed as the estimation technique. The GOF cut-off values (CFI and NNFI $=0.95 ;$ SRMR $\leq 0.08$; RMSEA $<0.08)$ were determined in accordance with model complexity $(12<m<30)$ and sample size $(n<250)$ specifications (Hair et al., 2006).

The measurement model GOF results indicated that very good fit was achieved for the four-factor model. A Satorra Bentler scaled chi-square value of 323.68, with 246 degrees of freedom and $p$ less than 0.000 , was obtained. The null hypothesis of exact fit was consequently rejected $(p<0.05)$. However, strong evidence of close fit was evident $(p=0.93$
$>0.05)$. The close fit result was underscored by the other results: RMSEA $=0.04$ (confidence intervals: 0.02, 0.05), CFI $=0.98, \mathrm{NNFI}=0.98, \mathrm{SRMR}=0.06$. Overall, there was strong evidence to suggest that the four-factor measurement model of the PCQ-24 produced a very good fit to the current data. The completely standardised factor loadings ranged from 0.53 to 0.82 for the self-efficacy subscale, 0.53 to 0.75 for the hope subscale, 0.27 to 0.74 for the resilience subscale, and 0.14 to 0.80 for the optimism subscale. Consistent with the results of the item analyses, the items with the two lowest loadings were item 13 (0.27) and item 20 (0.14).

The fit of the one-factor model was significantly worse $\left(\Delta \mathrm{S}-\mathrm{B} \chi_{(6)}^{2}=79.79, p<0.05\right)$ when compared with the fourfactor model. This result was further underscored by the GOF indices obtained for the one-factor model: RMSEA 0.07 (confidence intervals: 0.06, 0.07); NNFI $=0.95 ; \mathrm{CFI}=0.95$ and $\mathrm{SRMR}=0.07$. Although the GOF indices for this model could still be interpreted as indicating a well-fitting model, there was clear evidence to suggest that the four-factor model was superior to the one-factor model. Hypothesis 2a was therefore supported.

Based on the CFA procedure followed to examine the higher-order PsyCap factor described by Luthans, Avolio, Avey and Norman (2007), an attempt was made to fit a higher-order factor model (i.e. six items loading on each dimension, and four dimensions loading on the higher-order PsyCap variable), as a replication within the South African environment. Unfortunately, the model would not converge. LISREL provided the error message 'fitted covariance matrix is not positive definite'. As a follow-up strategy, the fourfactor CFA model was re-run, and the latent scores (Jöreskog, 2000) per latent variable (i.e. hope, optimism, self-efficacy and resilience) derived from the model were generated. These scores were exported to SPPS and an EFA (principle axis factoring with direct oblimin rotation) was conducted. The extraction of factors was based on the scree test and 'eigenvalue bigger than 1 ' rule. The results showed that one factor could be extracted, explaining $69.33 \%$ of the variance. The loadings were: self-efficacy, 0.84 ; hope, 0.87 ; resilience, 0.83 ; optimism, 0.79 . The results of this analysis provided partial support for Hypothesis $2 b$. 


\section{Discriminant validity}

The results for the series of CFAs of more restricted models (M2-M7), each time compared to the unconstrained model (M1) recorded in Table 2, revealed that the constrained models consistently fitted the data significantly worse that the unconstrained model, providing support for the discriminant validity of each subscale of the PCQ-24. Additional evidence of the discriminant validity of the four PCQ-24 subscales was evident after inspection of the magnitude of the correlations between the various subscales (see Table 1). According to Kline (1998), correlations in the order of 0.60 (and less) may be interpreted as providing support for discriminant validity. In this study, two of the intercorrelations slightly exceeded the 0.60 mark (i.e. optimism and hope, hope and self-efficacy). However, this was not interpreted as sufficient evidence to reject the notion that these PsyCap sub-dimensions are too highly correlated to warrant their independent definitions. The positive manifold of moderate correlations between the PsyCap sub-dimensions makes theoretical sense and confirms previous international research in this regard (e.g. Luthans, Avolio, Avey \& Norman, 2007). Hypothesis 3 was therefore supported.

\section{External validity}

In order to investigate the relationships of the PsyCap subdimensions to external variables, the results of the Pearson's product-moment correlations were inspected (see Table 1). The four sub-dimensions, as well as the PsyCap total score, were negatively and statistically significantly related with perceived stress, suggesting that individuals who report more hope, optimism, self-efficacy and resilience also report experiencing less perceived stress. This confirms previous research on this relationship (e.g. Avey et al., 2009). Furthermore, small to moderate significant correlations (ranging from 0.27 to 0.44 ) between the four PsyCap subdimensions, as well as the PsyCap total score, and workrelated burnout were evident from the results. Higher scores on the CBI indicate less burnout. Hence, these positive associations further confirm the notion that individuals who report higher levels of PsyCap also report experiencing less work-related burnout. Hypothesis 4 and Hypothesis 5 were therefore supported.

The results of the standard regression analysis, investigating the effects of the PsyCap sub-dimensions on each of the work-engagement sub-dimensions, are reported in Table 3. Optimism and self-efficacy emerged as the only two significant predictors of the engagement sub-dimension, vigour. This suggests that higher levels of vigour, which entails high energy levels and mental resilience, as well as a willingness to invest effort and persistence in one's work (Schaufeli \& Bakker, 2003), are best predicted by positive attributions about the future (optimism) and displays of confidence in

TABLE 2: Summary of goodness-of-fit statistics for the tests of discriminant validity for the Psychological Capital Questionnaire 24 subscales.

\begin{tabular}{|c|c|c|c|c|c|c|c|c|c|}
\hline Model & $\chi^{2}$ & $\mathrm{~S}-\mathrm{B} \chi^{2}$ & $d f$ & $\Delta d f$ & $\Delta \mathrm{S}-\mathrm{B} \chi^{2}$ & NNFI & CFI & $p_{\text {close fit }}$ & RMSEA \\
\hline $\mathrm{M}_{1}$ Unconstrained model & $435.77^{*}$ & $323.68^{*}$ & 246 & - & - & 0.98 & 0.98 & 0.93 & 0.040 \\
\hline $\mathrm{M}_{2}$ Constrained model: self-efficacy.hope $=1.00$ & $545.63^{*}$ & 410.67 & 247 & 1 & $36.41 *$ & 0.96 & 0.97 & 0.11 & 0.057 \\
\hline $\mathrm{M}_{3}$ Constrained model: self-efficacy.resilience $=1.00$ & $524.36^{*}$ & $387.16^{*}$ & 247 & 1 & $26.51^{*}$ & 0.97 & 0.97 & 0.30 & 0.053 \\
\hline $\mathrm{M}_{4}$ Constrained model: self-efficacy.optimism $=1.00$ & $551.09 *$ & $397.21 *$ & 247 & 1 & $10.02^{*}$ & 0.97 & 0.97 & 0.20 & 0.055 \\
\hline$M_{5}$ Constrained model: hope resilience $=1.00$ & $529.25^{*}$ & $396.35^{*}$ & 247 & 1 & $68.33^{*}$ & 0.97 & 0.97 & 0.21 & 0.055 \\
\hline $\mathrm{M}_{6}$ Constrained model: hope. optimism = 1.00 & $514.46^{*}$ & $374.44 *$ & 247 & 1 & $9.63^{*}$ & 0.97 & 0.97 & 0.45 & 0.051 \\
\hline $\mathrm{M}_{7}$ Constrained model: resilience. optimism $=1.00$ & $548.97^{*}$ & $399.00 *$ & 247 & 1 & $13.08^{*}$ & 0.97 & 0.97 & 0.19 & 0.055 \\
\hline
\end{tabular}

$\chi^{2}$, Normal theory weighted least square chi-square; $S$ - $B \chi^{2}$, Sattora-Bentler scaled chi-square; $d f$, degrees of freedom; NNFI, non-normed fit index; CFI, Comparative fit index; $p_{c l o s e f i t} p$-value for close fit; RMSEA, root mean square error of approximation.

$*, p<0.05$

TABLE 3: Regression analysis of the Psychological Capital sub-dimensions on the three work engagement sub-dimensions.

\begin{tabular}{|c|c|c|c|c|c|c|}
\hline \multirow[t]{2}{*}{ Model } & \multirow[t]{2}{*}{$R^{2}$} & \multicolumn{2}{|c|}{ Unstandardised coefficients } & \multirow{2}{*}{$\begin{array}{c}\text { Standardised } \\
\text { coefficients (Beta) }\end{array}$} & \multirow[t]{2}{*}{$t$} & \multirow[t]{2}{*}{ Significance } \\
\hline & & B & SE & & & \\
\hline Criterion: Vigour & 0.415 & - & - & - & - & - \\
\hline (Constant) & - & -4.51 & 1.48 & - & -3.04 & 0.00 \\
\hline PCQself-efficacy & - & 0.11 & 0.05 & 0.16 & 2.10 & $0.04 *$ \\
\hline PCQhope & - & 0.07 & 0.06 & 0.11 & 1.33 & 0.19 \\
\hline PCQresilience & - & 0.12 & 0.06 & 0.14 & 1.92 & 0.06 \\
\hline PCQoptimism & - & 0.29 & 0.06 & 0.36 & 5.03 & $0.00 *$ \\
\hline Criterion: Dedication & 0.424 & - & - & - & - & - \\
\hline (Constant) & - & -1.16 & 1.39 & - & -0.83 & 0.41 \\
\hline PCQself-efficacy & - & 0.13 & 0.05 & 0.19 & 2.53 & $0.01^{*}$ \\
\hline PCQhope & - & 0.19 & 0.05 & 0.27 & 3.45 & $0.00 *$ \\
\hline PCQresilience & - & 0.02 & 0.06 & 0.03 & 0.34 & 0.72 \\
\hline PCQoptimism & - & 0.21 & 0.05 & 0.28 & 3.87 & $0.00 *$ \\
\hline Criterion: Absorption & 0.193 & - & - & - & - & - \\
\hline (Constant) & - & 2.16 & 1.58 & - & 1.37 & 0.17 \\
\hline PCQhope & - & 0.07 & 0.06 & 0.11 & 1.14 & 0.26 \\
\hline PCQresilience & - & 0.12 & 0.07 & 0.15 & 1.77 & 0.08 \\
\hline PCQoptimism & - & 0.15 & 0.06 & 0.21 & 2.46 & $0.01^{*}$ \\
\hline
\end{tabular}

PCQ, Psychological Capital Questionnaire; $R^{2}$, proportion variance explained; B, regression coefficient; SE, standard error; $t$, obtained $t$-value. 
taking on and applying the necessary effort to succeed at a challenging task (self-efficacy). Resilience did not emerge as a significant predictor of vigour, although the results seem to suggest that it may play a role (marginally non-significant). This makes sense as PsyCap resilience refers to bouncing back after adversity to attain success, whilst the vigour component of engagement refers specifically to tapping into mental resilience whilst working (Schaufeli \& Bakker, 2003). In the second analysis optimism, hope and self-efficacy, emerged as significant predictors of dedication. Dedication occurs when an employee is strongly involved in their work and experiences a sense of significance, enthusiasm, inspiration, pride and challenge (Schaufeli \& Bakker, 2003). It seems that the fact that self-efficacious people thrive on challenges, the motivational component embedded in hope, and positive emotions associated with optimism (which may feed into enthusiasm, inspiration and pride) may all be drivers of dedication. In the last analysis only optimism emerged as a significant predictor of absorption. This result suggests that an optimistic attribution style, which impacts perception processes and associated behaviours, may affect absorption behaviours (i.e. being fully concentrated and happily engrossed in work). Hence, partial support for Hypothesis 6 was found.

To investigate the moderating effect of PsyCap in the relationship between stress and work-related burnout, the results of the moderated regression were inspected (Table 4 ). The results indicated that the model was significant $(p<0.05)$, and that it explained $38.4 \%$ of the variance in work-related burnout. Strong evidence for PsyCap as moderator was evident as the interaction term (PsyCap-Interaction) was significant at the 0.05 level. Hypothesis 7 was therefore supported.

\section{Discussion}

To date, fairly consistent psychometric properties (i.e. reliability and construct validity) of the PCQ-24 in several USA, but also non-USA, samples (Dawkins et al., 2013) have been reported. However, the only published South African study on the PCQ-24 (Du Plessis \& Barkhuizen, 2011) provided results that were not consistent with the current body of knowledge on the psychometric properties of the instrument. The results of the study clearly indicated a need to further investigate the portability of the instrument to the South African environment. Moreover, Luthans, Avolio, Avey \& Norman (2007, p. 567) identified the need 'to provide further evidence to justify the construct validity of this core construct (referring to PsyCap) using other samples in the
United States, as well across different cultural settings'. In South Africa, psychologists are required to be proactively involved in providing evidence that the tests are fair and unbiased (Van de Vijver \& Rothmann, 2004). Section 8 of the Employment Equity Act (Republic of South Africa, 1998) stipulates that:

psychological testing and other similar assessments are prohibited unless the test or the assessment being used (a) has been scientifically shown to be valid and reliable, (b) can be applied fairly to all employees; and (c) is not biased against any employee or group.

This implies that South African industrial and organisational psychologists should be actively pursuing the validation of instruments, especially imported instruments, for use in the unique South African environment. This study therefore attempted to address this research need by investigating the internal and external validity of the PCQ-24 as a measure of the PsyCap construct within South Africa.

The results of the reliability analysis corroborated with general trends reported for both USA and non-USA studies (Dawkins et al., 2013). That is, the self-efficacy and hope sub-dimension scales comfortably met the 0.70 cut-off for acceptable reliability. Consistent with previous trends the optimism and resilience sub-dimension scales obtained lower reliability. Two items were identified that compromised the internal consistency of the scales. Both are reversed scored items (the instrument contains only three such items). Reversescored items are known to reduce scale reliability (Schmitt \& Stults, 1985). For example, Marsh (1996) has demonstrated a negative relationship between the observation of a negatively keyed item factor and verbal ability. This suggests that language proficiency in the testing language may influence the testee's ability to interpret negatively keyed items. Others (e.g. Dehrmann, 2012; Gooty et al., 2009) have reported similar results on the PCQ-24 with regard to the reverse-scored items. Only about $30 \%$ of the current sample indicated English to be their first language, suggesting that language proficiency may be related to this result. Further South African research should be pursued to investigate this finding. Normally the problem of offending items would be salvaged by removing such items from the scale (e.g. Piccolo \& Colquitt, 2006). However, this would not be appropriate when the manner in which the PsyCap index score is calculated is taken into account. If an offending item were removed, sub-dimensions with more items would be more heavily weighted in the total index score. Therefore, the possibility of rewording these items for future South African use of the instrument should rather be investigated.

TABLE 4: Moderated regression analysis: Psychological capital as a moderator in the stress, work-related burnout relationship.

\begin{tabular}{|c|c|c|c|c|c|c|}
\hline \multirow[t]{2}{*}{ Model } & \multirow[t]{2}{*}{$R^{2}$} & \multicolumn{2}{|c|}{ Unstandardised coefficients } & \multirow{2}{*}{$\begin{array}{c}\text { Standardised } \\
\text { coefficients (Beta) }\end{array}$} & \multirow[t]{2}{*}{$t$} & \multirow[t]{2}{*}{ Significance } \\
\hline & & B & SE & & & \\
\hline Criterion: Work-related burnout & 0.384 & - & - & - & - & - \\
\hline (Constant) & - & 45.87 & 7.64 & - & 6.00 & 0.00 \\
\hline Stress Total & - & -0.98 & 0.26 & -1.49 & -3.76 & $0.00 *$ \\
\hline PCQ Total & - & -0.11 & 0.06 & -0.29 & -1.64 & 0.10 \\
\hline Stress $\times$ PCQ (PsyCap-interaction) & - & 0.01 & 0.002 & 0.83 & 2.43 & $0.02 *$ \\
\hline
\end{tabular}

$\mathrm{PCQ}$, Psychological Capital Questionnaire; $R^{2}$, proportion variance explained; B, regression coefficient; $\mathrm{SE}$, standard error; $t$, obtained $t$-value. 
The construct validity results provided evidence that the four-factor model fitted the data very well. Moreover, there was sufficient evidence to suggest that the four-factor model fitted the data better than a one-factor model. Unfortunately due to operational limitations the higher-order model could not be tested with CFA. The results of the EFA on the four sub-dimensions showed that one factor (PsyCap) could be extracted, providing some preliminary evidence of a higherorder factor underlying the four sub-dimensions. In addition, the results from the discriminant validity analysis (the series of competing CFA analyses, as well the investigation of the correlations between the variables) suggested that the four sub-dimensions are indeed empirically distinct. Although CFA is a well-established way to investigate construct validity, it should be noted that a more stringent test thereof, and the cross-cultural portability of the PsyCap construct, should be applied by conducting a full-scale invariance analysis (Dunbar, Theron \& Spangenberg, 2011; Vandenberg \& Lance, 2000). Such an invariance analysis will provide important information as to the extent to which possible bias (i.e. construct, method or item bias - which generally refers to the presence of nuisance or systematic error in measurement, Van de Vijver \& Leung, 2001) translates into a lack of equivalence of PsyCap scores ocross different groups (e.g. between US and South African respondents). For example, evidence of configural invariance and equivalence (Dunbar et al., 2011) will be a much stricter test of the construct validity of PsyCap when utilised in the South African environment, as well as on different sub-groups (e.g. ethnic, gender) in South Africa. Hence, future research should pursue a large-scale invariance or equivalence study within the South African environment. From a psychometric point of view, such a study will assist in establishing equivalence and eliminating bias in order to assist practitioners to maximise the validity of inferences that are drawn from PsyCap test scores (Van de Vijver \& Leung, 2011).

Although the external validity evidence provided in this study is fairly limited, being only focused on three variables (perceived stress, work-related burnout and work engagement), the results provide preliminary evidence that PsyCap is related in the expected manner to these variables. Moreover, the results suggested that PsyCap is indeed a moderator in the relationship between stress and work-related burnout. Given empirical support for the 'state-like' nature of PsyCap (e.g. Avey, Luthans \& Youssef, 2010) and the preliminary success of developmental interventions (e.g. Luthans et al., 2008; Luthans et al., 2010), the current results suggest that the use of PsyCap training to minimise the development of burnout from stress may be warranted. Moreover, the results further suggest that tailored PsyCap training interventions focusing only on self-efficacy and optimism, when time or financial resources are limited, may be a useful alternative in harnessing the potential of PsyCap for increased employee engagement.

Various limitations to this study should be noted. Firstly, although the sample is fairly representative of the three major ethnic groups in the Western Cape region where it was collected, it is not generalisable to the wider South African population. Sample was also only restricted to one industry. Replication is needed in this regard. Secondly, self-report measures were used in this study, increasing the problem of common method variance. Social desirability and response biases are common sources of method bias related to selfreport measures. These were not investigated, nor controlled for, in the current study. Lastly, the fact that the higher-order PsyCap model could not be tested with CFA is an important limitation that needs to be addressed in future studies.

\section{Conclusion}

This study contributes to the existing body of knowledge on the relatively new construct of PsyCap, specifically within the South African environment. Preliminary evidence of the internal and external validity of the PCQ-24 instrument was reported. In addition, the empirical distinctiveness of the PsyCap sub-dimensions was demonstrated in this study.

\section{Acknowledgements Competing interests}

The authors declare that they have no financial or personal relationship(s) that may have inappropriately influenced them in writing this article.

\section{Authors' contributions}

G.G-E. (Stellenbosch University) was responsible for writing up the article and the data analysis. M.H. (Stellenbosch University) gathered the data and wrote the original thesis.

\section{References}

Avey, J.B., Luthans, F., \& Jensen, S.M. (2009). Psychological capital: A positive resource for combating employee stress and turnover. Human Resource Management, 48(5), 677-693. http://dx.doi.org/10.1002/hrm.20294

Avey, J.B., Luthans, F., Smith, R.M., \& Palmer, N.F. (2010). Impact of positive psychological capital on employee well-being over time. Journal of Occupational Health Psychology, 15(1), 17-28. http://dx.doi.org/10.1037/a0016998, PMid:20063956

Avey, J.B., Luthans, F., \& Youssef, C.M. (2010). The additive value of positive psychological capital in predicting work attitudes and behaviors. Journal of Management, 36(2) 430-452. http://dx.doi.org/10.1177/0149206308329961

Avey, J.B., Reichard, R.J., Luthans, F., \& Mhatre, K.H. (2011). Meta-analysis of the impact of positive psychological capital on employee attitudes, behaviors, and performance. Human Resource Development Quarterly, 22(2), 127-152. http:// dx.doi.org/10.1002/hrdq.20070

Avey, J., Wernsing, T.S., \& Luthans, F. (2008). Can positive employees help positive organizational change? Impact of psychological capital and emotions on relevant attitudes and behaviours. The Journal of Applied Behavioural Science, 44(1), 4870. http://dx.doi.org/10.1177/0021886307311470

Avey, J., Wernsing, T.S., \& Mhatre, K.H. (2011). A longitudinal analysis of positive psychological constructs and emotions on stress, anxiety, and well-being. Journal of psychological constructs and emotions on stress, anxiety, and well-being. Journal of
Leadership \& Organizational Studies, 18(2), 216-228. http://dx.doi.org/10.1177/ Leadership \& Organizat
1548051810397368

Bandura, A. (1986). Social Foundations of Thought and Action. Englewood Cliffs, NJ: Prentice-Hall.

Cheung, F., Tang, C.S., \& Tang, S. (2011). Psychological capital as a moderator between emotional labor, burnout, and job satisfaction among school teachers in China. International Journal of Stress Management, 18, 348-371. http://dx.doi. org/10.1037/a0025787

Cohen, S., Kamarck, T., \& Mermelstein, R. (1983). A global measure of perceived stress. Journal of Health and Social Behavior, 24(4), 385-396. http://dx.doi.org/10.2307/ 2136404, PMid:6668417

Cordes, C.L., \& Dougherty, T.W. (1993). A review and integration of research on job burnout. Academy of Management Review, 18(4), 621-656. http://dx.doi.org/ 10.5465/AMR.1993.9402210153, http://dx.doi.org/10.2307/258593

Cotton, P. \& Hart, P.M. (2003). Occupational well-being and performance: A review of organisational health research, Australian Psychologist, 38(2), 118-127. http:// dx.doi.org/10.1080/00050060310001707117 
Cropanzano, R., Rupp, D.E., \& Byrne, Z.S. (2003). The relationship of emotional exhaustion to job performance ratings and organizational citizenship behaviour. Journal of Applied Psychology, 88, 160-169. http://dx.doi.org/10.1037/0021Journal of Applied Psychology,
9010.88.1.160, PMid:12675403

Culbertson, S.S., Fullagar, C.J., \& Mills, M.J. (2010). Feeling good and doing great: The relationships between psychological capital and well-being. Journal of Occupationa Health Psychology, 15(4), 421-433. http://dx.doi.org/10.1037/a0020720, PMid:21058856

Dawkins, S., Martin, A., Scott, J., \& Sanderson, K. (2013). Building on the positives: A psychometric review and critical analysis of the construct of psychological capital. Journal of Occupational and Organizational Psychology, 86(3), 348-370. http:// dx.doi.org/10.1111/joop.12007

De Braine, R., \& Roodt, G. (2011). The Job Demands-Resources model as predictor of work identity and work engagement: A comparative analysis. SA Journal of Industrial Psychology/SA Tydskrif vir Bedryfsielkunde, 37(2), Art. \#889, 11 pages. http://dx.doi.org/10.4102/sajip.v37i2.889

Dehrmann, L. (2012). Predictors of examination success in the SAICA qualifying examinations. Unpublished master's thesis, Stellenbosch University, South Africa.

Diamantopoulos, A., \& Sigauw, J.A. (2000). Introducing LISREL: A guide for the uninitiated. London, UK: SAGE Publications. PMCid:PMC1298088

Diener, E. (2000). Subjective well-being: The science of happiness, and a proposal for national index. American Psychologist, 55, 34-43. http://dx.doi.org/10.1037/ 0003-066X.55.1.34, PMid:11392863

Du Plessis, Y., \& Barkhuizen, N. (2011). Psychological capital, a requisite for organisational performance in South Africa. South African Journal of Economic and Management Sciences, 15(1), 16-30.

Du Plooy, J., \& Roodt, G. (2010). Work engagement, burnout and related constructs as predictors of turnover intentions. SA Journal of Industrial Psychology/SA Tydskrif vir Bedryfsielkunde, 36(1), Art. \#910, 13 pages.

Du Toit, M., \& Du Toit, S.H.C. (2001). Interactive LISREL: user's guide. Lincolnwood, IL: Scientific Software International. PMCid:PMC1729816

Dunbar, H., Theron, C., \& Spangenberg, H. (2011). A cross-validation study of the performance index. Management Dynamics, 20(3), 2-24.

Foxcroft, C.D. (1997). Psychological testing in South Africa: perspectives regarding ethical and fair practices. European Journal of Psychological Assessment, 13, 229-235. http://dx.doi.org/10.1027/1015-5759.13.3.229

Foxcroft, C. D., Roodt, G., \& Abrahams, F. (2001). Psychological assessment: A brie retrospective overview. In C. Foxcroft, \& G. Roodt (Eds.), An introduction to Psychological Assessment in the South African context (pp. 11-32). Cape Town South Africa: Oxford University Press.

Gooty, J., Gavin, M., Johnson, P.D., Frazier, L.M., \& Snow, B.D. (2009). In the eyes of the beholder: Transformational leadership positive psychological capital and performance. Journal of Leadership \& Organizational Studies, 15(4), 353-367. $\mathrm{http}: / / \mathrm{dx}$.doi.org/10.1177/1548051809332021

Hair, J.F., Black, B., Babin, B., Anderson, R.E., \& Tatham, R.L. (2006). Multivariate Dato Analysis. (6th edn.). New York, NY: Prentice Hall International.

Harter, J.K., Schmidt, F.L., \& Hayes, T.L. (2002). Business-unit-level relationship between employee satisfaction, employee engagement, and business outcomes: A meta-
analysis. Journal of Applied Psychology, 87(2), 268-279. http://dx.doi.org/10.1037/ 0021-9010.87.2.268, PMid:12002955

Hobfoll, S.E. (1989). Conservation of resources: A new attempt at conceptualizing stress. American Psychologist, 44(3), 513-524. http://dx.doi.org/10.1037/0003066X.44.3.513, PMid:2648906

Hobfoll, S.E. (2002). Social and psychological resources and adaptation. Review of General Psychology, 6, 307-324. http://dx.doi.org/10.1037/1089-2680.6.4.307

Hu, L., \& Bentler, P.M. (1999). Covariance structure analysis: Conventional criteria versus new alternatives. Structural Equation Modeling, 6(1), 1-55. http://dx.doi. org/10.1080/10705519909540118

Jöreskog, K.G. (2000). Latent variable scores and their uses. Retrieved April 12, 2013, from http://www.ssicentral.com/lisrel/techdocs/lvscores.pdf

Jöreskog, K.G., \& Sörbom, D. (2002). LISREL [Computer software]. Chicago, IL: Scientific Software International.

Kelloway, E.K. (1998). Using LISREL for Structural Equation Modeling. New York, NY: Sage Publications.

Kerlinger, F., \& Lee, H. (2000). Foundations of Behavioural Research. Florida: Harcourt College Publishers.

Kline, R.B. (1998). Principles and practice of structural equation modeling. New York, NY: Guilford.

Kristensen, T.S., Borritz, M., Villadsen, E., \& Christensen, K.B. (2005). The Copenhagen burnout inventory: A new tool for the assessment of burnout. Work \& Stress, 19(3), 192-207. http://dx.doi.org/10.1080/02678370500297720

Laschinger, H.K.S., \& Grau, A.L. (2012). The influence of personal dispositional factors and organizational resources on workplace violence, burnout, and health outcomes in new graduate nurses: A cross-sectional study. International Journal of Nursing Studies, 49, 282-291. http://dx.doi.org/10.1016/j.ijnurstu.2011.09.004, PMid:21978860

Lee, R.T., \& Ashforth, B.T. (1996). A meta-analytic examination of the correlates of the three dimensions of job burnout. Journal of Applied Psychology, 81(2), 123-133. http://dx.doi.org/10.1037/0021-9010.81.2.123, PMid:8603909

Lewis-Beck, M.S. (1980). Applied regression: An introduction. California: Sage Publications.

Liu, L., Chang, Y., Fu, J., Wang, J., \& Wang, L. (2012). The mediating role of psychological capital on the association between occupational stress and depressive symptoms
among Chinese physicians: A cross-sectional study. BMC Public Health, 12, 219-227. http://dx.doi.org/10.1186/1471-2458-12-219, PMid:22436106
Luthans, F. (2002). The need for and meaning of positive organizational behaviour. Journal of Organizational Behaviur, 23(6), 695-706. http://dx.doi.org/10.1002/ job.165

Luthans, F., Avey, J.B., Avolio, B.J., \& Peterson, S.J. (2010). The development and resulting performance impact of positive psychological capital. Human Resource Development Quarterly, 21, 41-67. http://dx.doi.org/10.1002/hrdq.20034

Luthans, F., Avey, J.B., \& Patera, J.L. (2008). Experimental analysis of a web-based intervention to develop positive psychological capital. Academy of Management Learning and Education, 7, 209-221. http://dx.doi.org/10.5465/AMLE.2008.32712618

Luthans, F., Avolio, B.J., Avey, J.B., \& Norman, S.M. (2007). Positive psychological capital: Measurement and relationship with performance and satisfaction. Personne Psychology, 60(3), 541-572. http://dx.doi.org/10.1111/j.1744-6570.2007.00083.x

Luthans, F. Norman, S.M., Avolio, B.J., \& Avey, J.B. (2008). The mediating role of psychological capital in the supportive organizational climate - employee performance relationship. Journal of Organizational Behavior, 29, 219-238. http://dx.doi.org/ 10.1002/job.507

Luthans, F., Avolio, B.J., Walumbwa, F.O., \& Li, W. (2005). The psychological capital of Chinese workers: Exploring the relationship with performance. Management and Organization Review, 1(2), 249-271. http://dx.doi.org/10.1111/j.1740-8784.2005. 00011.x

Luthans, F., Youssef, C.M., \& Avolio, B.J. (2007). Psychological capital: Developing the human competitive edge. Oxford, UK: Oxford University Press.

Marsh, H.W. (1996). Positive and negative global self-esteem: A substantively meaningfu distinction or artefacts? Journal of Personality and Social Psychology, 70(4), 810-819. $\mathrm{http}: / / \mathrm{dx}$.doi.org/10.1037/0022-3514.70.4.810, PMid:8636900

Maslach, C. (1982). Burnout: The cost of caring. Englewood Cliffs, NJ: Prentice-Hall.

Maslach, C., \& Goldberg, J. (1998). Prevention of burnout: new perspectives. Applied and Preventative Psychology, 7, 63-74. http://dx.doi.org/10.1016/S0962-1849(98) 80022-X

Maslach, C., Jackson, S.E., \& Leiter, M.P. (1986). Maslach Burnout Inventory Manual. (2nd edn.). Palo Alto, CA: Consulting Psychologist Press.

Maslach, C., Schaufeli, W.B., \& Leiter, M.P. (2001). Job burnout. Annual Review of Psychology, 53, 397-422. http://dx.doi.org/10.1146/annurev.psych.52.1.397

Meyer, T. (2008). Exploring the relationship between emotional intelligence, burnout and absenteeism of bus drivers in the scheduled public bus services industry. Unpublished research report, Stellenbosch University, South Africa.

Nigah, N., Davis., A.J., \& Hurrell, S.A. (2012). The impact of buddying on psychological capital and work engagement: an empirical study of socialization in the professional services sector. Thunderbird International Business Review, 54(6), 891-905. http:// dx.doi.org/10.1002/tie. 21510

Nunnally, J.C., \& Bernstein, I.H. (1994). Psychometric theory. (3rd edn.). New York NY: McGraw-Hill.

Oakland, T. (2004). Use of educational and psychological tests internationally. Applied Psychology: An International Review, 53(2), 157-172. http://dx.doi.org/10.1111/ j.1464-0597.2004.00166.x

Parker, S. (1998). Enhancing role-breath self efficacy: The roles of job enrichment and other organizational interventions. Journal of Applied Psychology, 83, 835-852. $\mathrm{http}: / / \mathrm{dx}$.doi.org/10.1037/0021-9010.83.6.835

Peterson, S.J., Luthans, F., Avolio, B.J., Walumbwa, F.O., \& Zhang, Z. (2011). Psychological capital and employee performance: A latent growth modelling approach. Personnel Psychology, 64, 427-450. http://dx.doi.org/10.1111/j.1744-6570.2011.01215.x

Piccolo, R.G., \& Conquitt, J.A. (2006). Transformational leadership and job behaviors: The mediating role of core job characteristics. Academy of Management Journal, 49, 327-340. http://dx.doi.org/10.5465/AMJ.2006.20786079

Rego, A., Sousa, F., Marques, C., \& Cunha, M.P. (2012). Authentic leadership promoting employees' psychological capital and creativity. Journal of Business Research, 65, 429-437. http://dx.doi.org/10.1016/j.jbusres.2011.10.003

Republic of South Africa. (1998). Employment Equity Act, No. 55 of 1998. Government Gazette 400, (19370), 19 October. Cape Town: Government Printers.

Roberts, S.J., Scherer, L.L., \& Bowyer, C.J. (2011). Job stress and incivility: What role does psychological capital play? Journal of Leadership \& Organizational Studies, 18(4), 449-458.

Rothmann, S., Steyn, L.J. \& Mostert, K. (2004). Stress, sense of coherence and work wellness in an electricity supply organization. South African Journal of Business Management 36(1), 55-63.

Salanova, M., Agut, S., \& Peiro, J.M. (2005). Linking organizational resources and work engagement to employee performance and customer loyalty: The mediation of service climate. Journal of Applied Psychology, 90(6), 1217-1227. http://dx.doi. org/10.1037/0021-9010.90.6.1217, PMid:16316275

Salovey, P., Rothman, A.J., Detweiler, J.B. \& Stewart, W.T. (2000). Emotional states and physical health. American Psychologist, 55(1), 110-121. http://dx.doi.org/10.1037/ 0003-066X.55.1.110

Satorra, A., \& Bentler, P.M. (1988). Scaling corrections for chi-square statistics in covariance structure analysis. Proceedings of the American Statistical Association, 308-313.

Satorra, A., \& Bentler, P.M. (1999). A scale difference chi-square test statistic for moment structure analysis. (UCLA Statistics Series 260). Los Angeles, CA: Department of Psychology, University of California.

Schaufeli, W.B., \& Bakker, A.B. (2001). Work and well-being: Towards a positive occupational health psychology. Gedrag en Organizatie, 14(5), 229-253.

Schaufeli, W.B., \& Bakker, A.B. (2003). Utrecht Work Engagement Scale. Preliminary Manual. Utrecht, The Netherlands: Occupational Health Psychology Unit, Utrecht University. PMCid:PMC1765719 
Schaufeli, W.B., \& Bakker, A.B. (2004). Job demands, job resources and their relationship with burnout and engagement: A multi-sample study. Journal of Organisational Behavior, 25, 293-315. http://dx.doi.org/10.1002/job.248

Schaufeli, W.B., \& Enzmann, D. (1998). The burnout companion to study \& practice Philadelphia, PA: Taylor \& Francis Inc.

Scheier, M.F., \& Carver, C.S. (1985). Optimism, coping, and health: Assessment and implications of generalized outcome expectancies. Health Psychology, 4, 219-247. http://dx.doi.org/10.1037/0278-6133.4.3.219, PMid:4029106

Schlebusch, L. (1998). Recent advances in stress research and implications for health and well-being. In L. Schlebusch (Ed.), South Africa beyond transition: Psychological well-being. Proceedings of the Third Annual Congress of the Psychological Society of South Africa (pp. 265-283). Pretoria, South Africa: Psychological Society of South Africa.

Schmitt, N., \& Stults, D.M. (1985). Factors defined by negatively keyed items: The result of careless respondents? Applied Psychological Measurement, 9, 367-373. http://dx.doi.org/10.1177/014662168500900405

Seligman, M.E.P., \& Csikszentmihalyi, M. (2000). Happiness, excellence, and optimal human functioning. American Psychologist, 55(1), 5-14. http://dx.doi.org/10.1037/ 0003-066X.55.1.5, PMid:11392865

Snyder, C.R. (2000). Handbook of Hope. San Diego, CA: Academic Press.

Snyder, C.R., Sympson, S., Ybasco, F., Borders, T., Babyak, M., \& Higgins, R. (1996). Development and validation of the state hope scale. Journal of Personality and Social Psychology, 70, 321-335.

SPSS. (2010). SPSS for Windows, Release 18.0.0 [Computer software]. Chicago, IL: SPSS Inc.

Sweetman, D., Luthans, F., Avey, J. B., \& Luthans, B.C. (2011). Relationship between positive psychological capital and creative performance. Canadian Journal of Administrative Sciences, 28, 4-13. http://dx.doi.org/10.1002/cjas.175
Tripathi, P. (2011). Employee well-being: Role of psychological capital. Amity Journal of Applied Psychology, 2(1), 18-22.

Van de Vijver, A.J.R. \& Rothmann, S. (2004) Assessment in multicultural groups: The South African Case. SA Journal of Industrial Psychology, 30(4), 1-7. http://dx.doi. org/10.4102/sajip.v30i4.169

Van de Vijver, F., \& Leung, K. (2001). Personality in cultural context: Methodologica issues. Journal of Personality, 69(6), 1007-1031. http://dx.doi.org/10.1111/14676494.696173

Van de Vijver, F.J.R., \& Leung, K. (2011). Equivalence and bias: A review of concepts, models, and data analytic procedures. In D. Matsumoto, \& F.J.R. van de Vijver, Cross cultural Research Methods in Psychology (pp. 17-45). New York, NY: Cambridge University Press.

Vandenberg, R.J., \& Lance, C.E. (2000). A review and synthesis of the measurement invariance literature: Suggestions, practices, and recommendations for organizational research. Organizational Research Methods, 3(1), 4-70. http://dx.doi.org/10.1177/ 109442810031002

Wagnild, G.M., \& Young, H.M. (1993). Development and psychometric evaluation of the resiliency scale. Journal of Nursing Management, 1(2), 165-178.

Wang, Y., Chang, Y., Fu, J., \& Wang, L. (2012). Work-family conflict and burnout among Health, 12, 915-923. http://dx.doi.org/10.1186/1471-2458-12-915, PMid:23107113

Wright, T.A., \& Bonett, D.G. (1997). The contribution of burnout to work performance. Journal of Organizational Behavior, 18(5), 491-499. http://dx.doi.org/10.1002/ (SICI)1099-1379(199709)18:5\%3C491::AID-JOB804\%3E3.0.CO;2-I

Xanthopoulou, D., Bakker, A.B., Demerouti, E., \& Schaufeli, W.B. (2009). Work engagement and financial returns: A diary study on the role of job and persona resources. Journal of Occupational and Organizational Psychology, 82(1), 183-200. http://dx.doi.org/10.1348/096317908X285633 